\title{
\#MeToo Jesus: Naming Jesus as a Victim of Sexual Abuse
}

\author{
Jayme R. Reaves \\ Coordinator for the Centre for Encountering the Bible at Sarum College, \\ Salisbury, UK \\ jreaves@sarum.ac.uk
}

\author{
David Tombs \\ Howard Paterson Chair of Theology and Public Issues at the \\ Univesity of Otago, Aotearoa, New Zealand \\ david.tombs@otago.ac.nz
}

\begin{abstract}
The \#MeToo hashtag and campaign raises important questions for Christian public theology. In 2017, a church sign at Gustavus Adolphus church in New York City connected Jesus with \#MeToo through Jesus' words 'You did this to me too' (Matthew 25:40). This church sign offers appropriate recognition of the theological solidarity of Jesus with \#MeToo at a metaphorical level, but this article argues a more direct historical connection should also be made. It examines work by Tombs (1999), Heath (2011), Gafney (2013), and Trainor (2014) that go beyond theological solidarity to identify Jesus as a victim of sexual abuse in a more historical and literal sense. It concludes that naming Jesus as victim of sexual abuse is not just a matter of correcting the historical record but can also help churches to address the damage caused by victim blaming or shaming.
\end{abstract}

\section{Keywords}

\#MeToo - \#ChurchToo - sexual abuse - crucifixion - sexualized violence - victims

\section{Introduction}

The \#MeToo movement has confirmed what feminists have long argued: abusive sexual behaviour is a widespread everyday occurrence in many 
different areas of life and work. Yet, instead of addressing these problems as a matter of urgency, the conventional social response has been avoidance. When harassment and abuse cannot be ignored completely, they are likely to be dismissed as an unremarkable part of everyday life. Trivializing harassment and assault as natural and normal pushes them to the margins of public concern and excludes them from proper public debate. The \#MeToo movement has sought to challenge these conventions and to break the silences that sustain the failure to address them. \#MeToo has thereby highlighted a critical public conversation on the extent to which assault and abuse are accepted and normalised. Both the harm done and the pervasive avoidance of the problem raise important questions for Christian public theology.

One creative public response to \#MeToo was offered in the early months of the \#MeToo movement by Gustavus Adolphus Lutheran church in New York City. Their church sign linking Jesus to \#MeToo (based on Jesus' words in Mt. 25) is briefly examined below. We suggest that this metaphorical or theological connection based on Mt. 25 is an appropriate and important response to \#MeToo, but a careful reading of the crucifixion narratives suggests an even more obvious connection to Jesus should be made. A number of works have suggested that Jesus should be identified as a victim of sexual abuse and sexual violence in a more literal sense and historical sense. Examples are discussed below, including the interpretation of crucifixion offered twenty years ago in Tombs (1999), as well as more recent works by Elaine Heath (2011), Wil Gafney (2013), and Michael Trainor (2014). ${ }^{1}$ The discussion of these works will note some common features in their argument. It will also suggest that the \#MeToo movement provides a timely opportunity for this historical acknowledgment of Jesus as a victim of sexual abuse to be taken up in a more open and sustained conversation within biblical studies and theology, as well as within the churches.

1 David Tombs, 'Crucifixion, State Terror, and Sexual Abuse', Union Seminary Quarterly Review, 53 (Autumn 1999), 89-109, OUR archive version, <http://hdl.handle.net/10523/6067>; Elaine A. Heath, We Were the Least of These: Reading the Bible with Survivors of Sexual Abuse (Grand Rapids, MI: Brazos, 2011); Wil Gafney, 'Crucifixion and Sexual Violence', HuffPost (28 March 2013), <https://www.huffingtonpost.com/rev-wil-gafney-phd/crucifixion-and -sexual-violence_b_2965369.html> [accessed 8 September 2018]; Michael Trainor, Body of Jesus and Sexual Abuse: How the Gospel Passion Narrative Informs a Pastoral Approach. Eugene, OR: Wipf \& Stock Publishers, 2014]. We offer these as examples from different countries that explicitly name Jesus as a victim of sexual abuse. 
The origins of 'Me Too' date back to the late 199os when activist Tarana Burke worked as a youth camp director. On her organisation's website, Burke tells the origin story of 'Me Too', when a thirteen-year-old girl sought her out to share her experience of sexual abuse. Burke notes her difficulty in hearing the young girl's story, saying:

I could not muster the energy to tell her that I understood, that I connected, that I could feel her pain ... I could not find the strength to say out loud the words that were ringing in my head over and over again as she tried to tell me what she had endured ... I watched her put her mask back on and go back into the world like she was all alone and I couldn't even bring myself to whisper ... me too. ${ }^{2}$

Ten years later, Burke started a non-profit organisation called Just Be that worked to assist young women of colour who were victims of sexual abuse and assault. As part of the work, in 2006 Burke started 'Me Too', a movement that sought to provide resources and a platform for survivors of sexual abuse to share their story and bear witness to the trauma experienced by other young women. ${ }^{3}$

The twitter hashtag \#MeToo then became part of the cultural zeitgeist when actress Alyssa Milano used it in the autumn of 2017. Milano hoped to encourage women to share their own stories as a reaction to the tales of sexual assault and harassment perpetuated by Harvey Weinstein and others in the film and TV industry. Two days after the initial tweet, Milano gave public credit to Burke, with both Milano and Burke emphasizing the campaign is about many survivors of sexual abuse and assault. ${ }^{4}$ As soon as it began to appear on social

2 Tarana Burke, 'The Inception', Just Be, Incorporated, <http://justbeinc.wixsite.com/just beinc/the-me-too-movement-cmml $>$ [accessed on 19 September 2018]. Also see, Cassandra Santiago and Doug Criss, 'An activist, a little girl and the heartbreaking origin of "Me too", $C N N$ (17 October 2017), <https://edition.cnn.com/2017/10/17/us/me-too-tarana-burke-origin -trnd/index.html> and Sandra E. Garcia, 'The woman who created \#MeToo long before hashtags', New York Times (17 October 2017) <https://nyti.ms/2zocwiU> [both accessed 19 September 2018].

3 Abby Ohlheiser, 'The woman behind 'Me Too' knew the power of the phrase when she created it—10 years ago', Washington Post, (19 October 2017), <https://www.washingtonpost .com/news/the-intersect/wp/2017/10/19/the-woman-behind-me-too-knew-the-power-of -the-phrase-when-she-created-it-10-years-ago/> [accessed 16 August 2019].

4 Sandra E. Garcia, 'The woman who created \#MeToo long before hashtags', New York Times, (17 October 2017), <https://nyti.ms/2zocwiU > [accessed 19 September 2018]. 
media sites, the movement grew into something larger, with individuals coming forward across all walks of life to share the stories that they too had been victims of sexual abuse in its various and horrifying forms. In the first twentyfour hours, the hashtag had been used more than 30,000 times on Twitter ${ }^{5}$ and by almost five million people in twelve million posts on Facebook. ${ }^{6}$

The extent to which \#MeToo resonated with the wider public points to the prevalence of sexual assault, harassment, and abuse. This is further confirmed in a wide range of publicly available reports and statistics in different countries. For example:

- The World Health Organisation reports violence against women is a 'major public health problem', with global estimates suggesting about one in three $(35 \%)$ of women worldwide have experienced either physical and/or sexual intimate partner violence or non-partner sexual violence in their lifetime. ${ }^{7}$

- US-based statistics show that every single day more than 570 people experience sexual violence. ${ }^{8}$

- Rape Crisis England \& Wales report 85,000 women and 12,000 men are raped (includes rape and attempted rape) and almost 500,000 adults are sexually assaulted in England and Wales every year. ${ }^{9}$

- South African sources cite some of the highest rates of rape in the world and report a $53 \%$ increase in sexual violence against women since $2016 .{ }^{10}$

5 Catherine Powell, 'How \#MeToo Has Spread Like Wildfire Around the World', Newsweek, (15 December 2017). Powell also notes connected hashtags and movements in other countries and respective languages which are modelled on or direct translations of the \#MeToo movement.

6 'More than $12 \mathrm{M}$ 'Me Too' Facebook posts, comments, reactions in 24 hours'. cBs News (17 October 2017), <https://www.cbsnews.com/news/metoo-more-than-12-million-face book-posts-comments-reactions-24-hours/> [accessed 12 August 2018].

7 World Health Organisation, Factsheet: Violence Against Women, January 2016, <http:// www.who.int/mediacentre/factsheets/fs239/en/> [accessed 19 September 2018].

8 Alanna Vagianos, ' 30 alarming statistics that show the reality of sexual violence in America', Huffington Post, (5 April 2017), <https://www.huffingtonpost.com/entry/sexual -assault-statistics_us_58e24c14e4boc $777 f 788 \mathrm{~d} 24 \mathrm{f}>$, [accessed on 12 August 2018].

9 This statistic equates to roughly 11 rapes (of adults alone) every hour . Rape Crisis England \& Wales, 'Rape Crisis England \& Wales headline statistics 2017-18', < https://rape crisis.org.uk/get-informed/about-sexual-violence/statistics-sexual-violence/> [accessed 19 November 2019].

10 Lyn Snodgrass, 'Survivors of sexual violence in South Africa are finally finding their voices,' The Conversation, (14 November 2018), <https://theconversation.com/survivors -of-sexual-violence-in-south-africa-are-finally-finding-their-voices-106458> [accessed on 14 August 2019], referring to Statistics South Africa, 'Crime Against Women in South Africa: Report 03-40-05, May 2018' <http://www.statssa.gov.za/publications/Report-03-40-05/ Report-03-40-05June2018.pdf> [accessed on 14 August 2019]. 
- In Australia, the government's personal safety statistics (2016) indicate an estimated $18 \%$ of women (over 15 years old) have experienced sexual violence, with a corresponding figure of $5 \%$ for men. ${ }^{11}$

- In 2014, the New Zealand Ministry of Justice reported 15\% of adults "had experienced one or more incidents of sexual violence at some point during their lives," with women $(24 \%)$ more likely than men $(6 \%) .^{12}$

Invariably, these various statistics also note that under-reporting is a serious issue and that the real figures are most likely higher still. ${ }^{13}$ Sexual assault and harassment are experienced by people from all backgrounds but an intersectional analysis shows that some factors place some social groups other than women and girls at even higher risk.

- The National Centre for Transgender Equality in the United States report $47 \%$ of transgendered individuals have been sexually assaulted and $10 \%$ report they have been sexually assaulted within the past year. ${ }^{14}$

- Prevalence of rape and sexual assault is twice as high for those who experience disability, and women with disabilities are four times more likely to experience sexual assault than women without disabilities. ${ }^{15}$

While many early voices for the \#MeToo movement were based in the United States, it quickly spread through social media to a global audience. The movement also spread across different areas of employment and different aspects of women's lives. ${ }^{16}$ Women came forward to tell their stories of sexual abuse

11 Australian Bureau of Statistics (ABS), 'Prevalence of violence since the age of 15,' Personal Safety, Australia, 2016, ABS cat. no. 4906.o. (ABS: Canberra, 2017), <https:// www.abs.gov.au/ausstats/abs@.nsf/Lookup/by\%2oSubject/4906.o 2016 Main\%20 Features Prevalence\%20of\%2oviolence\%2osince\%2othe\%2oage\%20of\%2015 6> [accessed on 14 August 2019].

12 New Zealand Ministry of Justice, 'Research \& Data: Sexual Violence', 30 May 2018 $<$ https://www.justice.govt.nz/justice-sector-policy/research-data/nzcass/survey-results/ results-by-subject/sexual-violence/> [accessed 14 August 2019].

13 See also Meera Senthilingam, 'Sexual Harassment: How it stands around the globe', CNN Health (29 November 2017), <https://edition.cnn.com/2017/11/25/health/sexual -harassment-violence-abuse-global-levels/index.html> [accessed on 1 August 2018].

14 S. E., James, J. L., Herman, S., Rankin, M., Keisling, L., Mottet, \& M., Anafi, The Report of the 2015 U. S. Transgender Survey, (Washington, DC: National Center for Transgender Equality, 2016), 15, <https://www.transequality.org/sites/default/files/docs/USTS-Full-Report -FINAL.PDF $>$ [accessed on 1 August 2018].

15 Emily Flores, 'The \#MeToo Movement Hasn't Been Inclusive of the Disability Community', Teen Vogue, (24 April 2018) <https://www.teenvogue.com/story/the-metoo-movement -hasnt-been-inclusive-of-the-disability-community> [accessed on 1 August 2018].

16 Early initaitives included a new action plan called Time's Up focusing on setting up a legal defense fund to support women working as janitors, nurses, hospitality industry and farm or factory workers to protect themselves after reporting abuse. Cara Buckley, 'Powerful Hollywood Women Unveil Anti-Harassment Action Plan', New York Times, 
experienced in many different contexts, but alongside the variety there was often also a common pattern. Many of the stories highlighted the dynamics of power, control, inequality, and sense of male entitlement. The stories also recorded the obstacles women faced when they spoke of their experience, and how frequently they were not believed, or their experience was dismissed as normal. ${ }^{17}$ Some men also spoke of their experiences and the taboos and silences around speaking of sexual violence against men. ${ }^{18}$

(1 January 2018), <https://www.nytimes.com/2018/o1/o1/movies/times-up-hollywood -women-sexual-harassment.html> [accessed on 12 August 2018]. There were also increased reports from both faculty and students in academic institutions in the U. S.; see Nell Gluckman, Brock Read, Katherine Mangan, and Bianca Quilantan, 'Sexual Harassment and Assault in Higher Ed: What's happened since Weinstein', The Chronicle of Higher Education, (13 November 2017) <https://www.chronicle.com/article/Trackin g-Higher-Ed-s-MeToo/241757> [accessed 12 August 2018].

17 In September 2018, the impact of \#MeToo was seen in the \#WhyIDidNotReport movement in support of Christine Blasey Ford and her allegation against Brett Kavanaugh during his Senate confirmation process as a Supreme Court Justice. The hashtag was prompted by a tweet from President Donald Trump which sought to dismiss the allegation by asking: 'Why didn't somebody call the FBI 36 years ago?'; A J Willingham and Christina Maxouris, 'These tweets show why people don't report sexual assaults', $C N N$, 21 September 2018, <https://www.cnn.com/2018/o9/21/health/why-i-didnt-report-tweets-trnd/index.html> [accessed 21 September 2018]. Earlier in 2018, the journalist John Blake linked the disbelief of women who report with the disbelief of the women who first witnessed to the resurrection; John Blake, 'How Easter became a \#MeToo moment', CNN (31 March 2018) $<$ https://edition.cnn.com/2018/o3/30/world/easter-metoo-jesus/index.html> [accessed 19 November 2019].

18 Underreporting of sexual violence against men and boys makes it difficult to give precise figures, but as with violence against women and girls, men and boys of every background can experience sexual assault, regardless of age, class, ethnicity or sexual orientation; David Rutledge, 'In the age of \#MeToo, how do we talk about sexual violence against men?' $A B C$ News (25 February 2018) <https://www.abc.net.au/news/2018-02-25/men-sexual-assault -and-the-metoo-conversation/9465022> [accessed 16 August 2019]; Catie Edmondson and Marc Tracy, "It Can Happen Even to Guys": Ohio State Wrestlers Detail Abuse, Saying \#UsToo', New York Times, (2 August 2018) < https://www.nytimes.com/2018/08/02/us/poli tics/ohio-state-wrestlers-abuse-me-too.html $>$ [accessed 16 August 2019]; Hanna Rosin, 'When Men Are Raped', Slate, (29 April 2014) <https://slate.com/human-interest/2014/04/ male-rape-in-america-a-new-study-reveals-that-men-are-sexually-assaulted-almost-asoften-as-women.html> [accessed 16 August 2019]. And, as with women and girls, some groups are especially at risk. The National Intimate Partner and Sexual Violence Survey found that 4 in 10 gay men $(40 \%)$, nearly half of bisexual men $(47 \%)$, and 1 in 5 heterosexual men $(21 \%)$ have experienced sexual violence other than rape in their lifetime. The US Center for Disease Control notes 'this translates into nearly 1.1 million gay men, 903,000 bisexual men, and 21.6 million heterosexual men'; Center for Disease Control (US), 'National Intimate Partner and Sexual Violence Survey: An Overview of 2010 Findings on Victimization by Sexual Orientation', <https://www.cdc.gov/violenceprevention/pdf/ cdc_nisvs_victimization_final-a.pdf> [accessed on 1 August 2018]. 
Within church communities, two specific hashtags came to the fore: \#ChurchToo and \#SilenceIsNotSpiritual. \#ChurchToo started on Twitter with two women-Hannah Paasch and Emily Joy-who have spent years working for gender inclusion within churches and against patriarchal purity culture. \#ChurchToo linked the \#MeToo movement to the stories of abuse in the church and other religious communities, with people sharing their experiences of being raped and assaulted by male religious leadership. Then, when those experiences were reported to the church, they - the victims - were told to repent, leading to religious communities perpetuating sexual violence through inaction or further victimization. Women in relationships marked by domestic violence and sexual abuse give examples of being told to submit to their husbands and fathers because it's what God wants..$^{19}$ There are also stories of perpetrators who publicly confessed to molestation, harassment, and assault, but were praised for their bravery and honesty with no criminal consequences. ${ }^{20}$ Furthermore, even in the context of a progressive church setting, a woman entering into an internship in ministry tells the story of a male congregant who 'complained to the senior pastor that he could not focus on the sermon when [she] preached because he couldn't not sexualize [her]'. The solution devised between the senior pastor and congregant was for the congregant to get the female intern's preaching schedule in advance 'so he could choose other services to attend without the distraction of [her] presence in leadership..21

Both \#ChurchToo and the related evangelical movement called \#SilenceIsNotSpiritual seek to highlight the church's legacy of protecting abusers, and the gendered ways in which these reports and confessions

19 Tara Isabella Burton, ‘\#ChurchToo: abuse survivors speak out about harassment in their religious communities', Vox (22 November 2017), <https://www.vox.com/ identities/2017/11/22/16690384/churchtoo-abuse-survivors-harassment-religiouscommunities> [accessed on 12 August 2018]; Casey Quackenbush, 'The Religious Community Is Speaking Out Against Sexual Violence With \#ChurchToo', Time Magazine, (22 November 2017), <http://time.com/5034546/me-too-church-too-sexual-abuse/> [accessed 12 August 2018].

20 Neil J. Young, 'In Church, Confessing To Sexual Abuse Can Win You a Standing Ovation', The Huffington Post, (27 January 2018), <https://www.huffpost.com/entry/opinion -young-evangelicals-metoo_n_5a6b614ee4boddb658c6o8b3> [accessed 16 August 2019]; Scott Savage, 'This Is How Churches Should Respond to Abuse', Relevant Magazine, (18 June 2018) <https://relevantmagazine.com/current/this-is-how-churches-should -respond-to-abuse/> [accessed 14 August 2019].

21 Pastor Jennifer, Pastor Jennifer Preaching (blog), 'Dear Church: \#MeToo' (17 October 2017), $<$ https://pastorjenniferpreaching.wordpress.com/2017/10/17/dear-church-metoo/> [accessed 16 August 2019]. 
are being addressed-or not addressed-as the case may be. The \#SilenceIsNotSpiritual statement explains:

For too long the voices of women and girls who suffer violence have been marginalized, ignored or silenced. The global Church has been slow to speak up and take action. Until Now. More than 150 leaders from across the world are calling upon the global faith community to stop standing by and start standing up for women and girls who experience violence.... We face a defining moment as a Church ... a kairos moment-[or] a window of opportunity to bring healing in the world and in the church [and] doing nothing is not acceptable. Silence is not spiritual ... We are calling churches, particularly those in our stream of the Christian faithEvangelical churches, to end the silence and stop all participation in violence against women. ${ }^{22}$

\subsection{You Have Done it to \#MeToo}

In the midst of the media storm around \#MeToo in October 2017, Gustavus Adolphus Lutheran Church in New York City made a theological connection to the movement which was shared widely on social media. The church sign at the front of the building displayed the words: 'Jesus said, as you have done it to them you have done it to \#MeToo.' The creative paraphrase of Matthew 25:40 is obvious: 'And the king will answer them, 'Truly I tell you, just as you did it to one of the least of these who are members of my family, you did it to me' (NRSV).

It is not known what exactly the author of the sign had in mind, and perhaps different people at the church understood it in different ways. It would be reasonable to suspect that many would have understood this as a theological recognition that Christ stands in solidarity and shares in the experiences of those who say \#MeToo. The parable of judgment in Mt. 25:31-46 speaks of the separation of the sheep and the goats (Mt. 25:32). The judgement is given by the Son of Man (Mt. 25:31) who is presented as 'the king' (Mt. 25:34), and as Mt. 25:35-46 make clear, the king is to be read as Christ. The parable teaches that the ways that a follower treats others is also the way the follower treats Christ. More specifically, Christ identifies especially with the 'least of these'. He shares in their vulnerability and experiences whatever they experience as the hungry, the thirsty, the stranger, and the naked. Therefore, at a theological www.silenceisnotspiritual.org/statement $>$ [accessed on 12 August 2018]. While not all victims of sexual abuse are women, the vast majority of the ones we know about are. 
level, it is a short and easy step to identify Christ symbolically and metaphorically with those who have endured sexual abuse. The parable teaches that Christ has shared in their suffering: 'I was naked and you gave me clothing, I was sick and you took care of me, I was in prison and you visited me' (Mt. 15:36).

A similar theological conviction can be seen in a recent sermon by Daniel Glaze. Glaze is a progressive Baptist pastor in Richmond, Virginia, who asked in his sermon: 'Will we take advantage of those who are vulnerable in our midst, or will we take seriously the call to care for Christ? [For w] hen I was hungry, you fed me. When I was being harassed, you spoke up and it was stopped.'23

Likewise, the Melbourne-based writer Beth Crisp makes a number of bibli$\mathrm{cal}$ and theological links between the experiences of Jesus and the experiences of those who have suffered sexual abuse. ${ }^{24}$ In her collection of mediations for Lent, Beyond Crucifixion: Meditations on Sexual Abuse (2010), Crisp's reflection on Jesus foretelling the rejection of the Son of Man in Luke 9:21-25 opens with the statement 'The experience of sexual abuse is too often the experience of rejection. ${ }^{25}$ Likewise, her reflection on crucifixion in John 18:1-19.42 begins: 'Many survivors have likened their experience of abuse to that of crucifixion.' ${ }^{26}$

The connections and reflections offered by the sign board at Gustavus Adolfus Lutheran Church, pastors like Glaze, and writers like Crisp are all creative and meaningful ways to affirm that Christ shares in the experiences of all who have suffered sexual harassment or sexual assault. Yet, in the context of \#MeToo, it is also appropriate to go beyond these affirmations of theological solidarity and ask a more historical question: did Jesus himself experience

23 Baptist Women in Ministry, 'Preaching \#MeToo by Daniel Glaze', (13 December 2017), <http://bwim.info/pamsblog/preaching-metoo-by-daniel-glaze/> [accessed on 4 January 2018].

24 See especially, Beth R. Crisp, 'Beyond Crucifixion: Remaining Christian After Sexual Abuse', Theology and Sexuality, 15:1 (January 2009), 65-76; Crisp, Beyond Crucifixion: Meditations on Surviving Sexual Abuse, (London: Darton, Longman and Todd, 2010). Crisp has also highlighted the silence which pervades around sexual abuse and the spiritual impacts of sexual abuse; Crisp, 'Silence and Silenced: Implications for the Spirituality of Survivors of Sexual Abuse', Feminist Theology, 18:3 (2010), 277-93; Crisp, 'Spirituality and Sexual Abuse: Issues and Dilemmas for Survivors', Theology \& Sexuality 13:3 (May 2007), 301-14.

25 Crisp, Beyond Crucifixion: Meditations, p. 3.

26 Crisp, Beyond Crucifixion: Meditations, p. 99. For example, in 2016, David Sharp chained himself to a seven-foot high wooden cross outside St Andrew's Cathedral in Glasgow to protest against church sexual abuse; see Stephen Naysmith, 'Man to stage 'crucifixion' to highlight abuse', The Herald, [Glasgow] (20 August 2016).

Crisp, 'The Spiritual Implications of Sexual Abuse: Not Just an Issue for Religious Women?', Feminist Theology 20:2 (2012), 133-45. 
sexual abuse? As the British sociologist of religion Linda Woodhead says, this 'initially sounds bizarre. ${ }^{27}$ It seems ridiculous to even ask the question. Yet Woodhead adds: 'Look at it more closely, however, and the suggestion stands up. ${ }^{28}$

\section{Naming Jesus as a Victim of Sexual Abuse}

\subsection{Crucifixion, State Terror, and Sexual Abuse}

As far as we know, the first discussion linking crucifixion and sexual abuse was the paper given by Tombs in Krakow, Poland at the 1998 International Meeting of the Society of Biblical Literature. ${ }^{29}$ This presentation was published the following year as 'Crucifixion, State Terror, and Sexual Abuse'. ${ }^{30}$ The article draws on Latin American liberation theology hermeneutics to read the crucifixion narratives in light of Latin American torture reports. ${ }^{31}$ The central claim is that testimonies to torture and prisoner abuse in Latin America under authoritarian regimes in the 1970 s and 1980 s can offer two especially valuable insights into how the Romans used crucifixion in the first century. ${ }^{32}$ First, torture

27 Linda Woodhead, 'Is Jesus the Latest-or Was He the First-Victim of \#MeToo?', The Daily Telegraph (27 March 2018), <https://www.telegraph.co.uk/news/2018/03/27/ jesus-latest-first-victim-metoo/> [accessed 16 August 2019]. Woodhead's article is a response to Katie B. Edwards and David Tombs, '\#HimToo-Why Jesus Should be Recognised as a Victim of Sexual Abuse', The Conversation (23 March 2018), <https://theconversation .com/himtoo-why-jesus-should-be-recognised-as-a-victim-of-sexual-violence-93677> [accessed 25 March 2018].

28 Woodhead, 'Is Jesus the Latest—or Was He the First—Victim of \#MeToo?'; see also Kaya Burgess, '\#HimToo: Jesus was a sex abuse victim, say scholars', The Times, (27 March 2018) $<$ https://www.thetimes.co.uk/article/himtoo-jesus-was-sex-abuse-victim-say-scholars $-5 \operatorname{lm} x_{3} \operatorname{cg} 58>$ [accessed 16 August 2019].

29 David Tombs, 'Biblical Interpretation in Latin America: Crucifixion, State Terror, and Sexual Abuse', in the Biblical Hermeneutics Section at the Society of Biblical Literature International Meeting, Krakow, 18-22 July 1998.

$30 \quad$ David Tombs, 'Crucifixion, State Terror, and Sexual Abuse', Union Seminary Quarterly Review, 53 (Autumn 1999), 89-109. Available at Otago University Research Archive, $<$ http://hdl.handle.net/10523/6067> At the time, Tombs was a Lecturer in Theology at what is now the University of Roehampton, London.

31 On the liberationist approach this reading draws upon, see David Tombs, 'The Hermeneutics of Liberation' in Stanley E. Porter and David Tombs, eds., Approaches to New Testament Study, (Sheffield: Sheffield Academic Press, 1995), pp. 310-55. David Tombs, Latin American Liberation Theology, (Religion in the Americas Series Vol. 1; Boston and Leiden: Brill, 2002).

32 Since then, the argument has been developed further in a sequence of conference papers, and in publications, for example: David Tombs, 'Honour, Shame and Conquest: Male 
reports suggest how crucifixion had a political purpose and was used as an instrument of state terror. As Elaine Scarry's work has shown, ${ }^{33}$ torture can effectively re-inscribe political power by degrading and dehumanizing someone who is viewed as a threat. ${ }^{34} \mathrm{~A}$ public execution involving torture, such as crucifixion, offers a dramatic spectacle which communicates this political message in an especially graphic way. Public torture and execution goes beyond the immediate victim to serve a wider political purpose. Second, torture reports reveal the high frequency of sexual violence in state terror torture practices. When the purpose of torture is seen as the inscription and display of power the significance of sexual violence becomes more understandable. Sexual violence can be used to convey the power and control of the crucifier by enacting and displaying the vulnerability and defeat of the victim. Punitive sexual violence can also be an especially effective way by which to humiliate and degrade a victim because its meaning is so densely encoded with social and cultural values around gender, identity, power and conquest. ${ }^{35}$ The use and meaning of sexual violence for this purpose is as clear in Roman crucifixions as it is in much of contemporary torture, not just in Latin American but around the world. The notorious photos from Abu Ghraib convey a similar message. ${ }^{36}$

In particular, the article highlights the role of stripping and enforced naked exposure in the mockery and mistreatment of Jesus in preparation for the cross and on the cross itself:

Identity, Sexual Violence and the Body Politic', Journal of Hispanic/Latino Theology, 9:4 (May 2002), 21-40; Tombs, 'Prisoner Abuse: From Abu Ghraib to The Passion of The Christ' in Linda Hogan and Dylan Lehrke, eds, Religions and the Politics of Peace and Conflict (Princeton, NJ: Princeton Theological Monograph Series, 2009), pp. 179-205; Tombs, 'Silent No More: Sexual Violence in Conflict as a Challenge to the Worldwide Church', Acta Theologica, 34:2 (December 2014), 142-60; Tombs, 'Lived Religion and the Intolerance of the Cross' in Ruard Ganzevoort and Srdjan Sremac, eds, Lived Religion and Politics of (In)tolerance, Palgrave Studies in Lived Religion and Societal Changes, (London: Palgrave McMillan, 2017), pp. 63-83; Tombs, The Crucifixion of Jesus: Torture, Sexual Abuse, and the Scandal of the Cross (London: Routledge, forthcoming 2020).

33 Elaine Scarry, The Body in Pain: The Making and Unmaking of the World, (New York: Oxford University Press, 1987).

34 See also William T. Cavanaugh, Torture and Eucharist: Theology, Politics and the Body of Christ, Challenges in Contemporary Theology series (Oxford: Blackwell, 1998). Cavanaugh's excellent book on torture and Eucharist first appeared in 1998, but despite its insights on the political significance and religious dimension to torture, it did not address the sexual violence of torture at any length, or examine sexual violence in relation to crucifixion, or how the memory of sexual violence might be a concern for the Eucharist.

35 Tombs, 'Honour, Shame and Conquest: Male Identity, Sexual Violence and the Body Politic'.

36 Tombs, 'Prisoner Abuse: From Abu Ghraib to The Passion of The Christ'. 
Based on what the Gospel texts themselves indicate, the sexual element in the abuse is unavoidable. An adult man was stripped naked for flogging, then dressed in an insulting way to be mocked, struck and spat at by a multitude of soldiers before being stripped again and reclothed for his journey ... only to be stripped again and displayed to die whilst naked to a mocking crowd. When the textual presentation is stated like this, the sexual element of the abuse becomes clear; the assertion is controversial only in so far as it seems startling in view of usual presentations. The sexual element to the torture is downplayed in artistic representations of the crucifixion that show Jesus wearing a loincloth. These images distance us from the biblical text, perhaps because the sexual element has been too disturbing to confront. ${ }^{37}$

Furthermore, both the Matthew 27 and Mark 15 crucifixion narratives describe Jesus being handed over weakened and naked — already a condemned man without any recourse to justice-to soldiers who took him inside the praetorium and assembled the other troops' (Mt 27: 26-27; Mk 15: 15-16). ${ }^{38}$ Testimonies of victims who experienced gang rape and other forms of sexual violence in clandestine torture cells in Latin America provide many stories of ways in which security forces humiliate and abuse political prisoners. ${ }^{39}$ Although it is impossible to say with certainty, evidence of prisoner abuses in Roman sources suggest it would not have been unusual if Jesus' crucifixion had been preceded by other forms of sexual violence and mockery. Historian Richard Trexler claims that anal rape of male captives was 'a practice notoriously rife in the ancient world. ${ }^{\prime 0}$ With the prevalence of contemporary stories in the media of sexualized violence and abuse perpetrated by military upon prisoners worldwide, it is not beyond the realm of possibility that similar sexual humiliations may have been elements in the mockery of Jesus. ${ }^{41}$

37 Tombs, 'Crucifixion, State Terror, and Sexual Abuse', 104.

38 Ibid., 104-105.

39 David Tombs, 'Unspeakable Violence: The Truth Commissions in El Salvador and Guatemala' in Iain Maclean, ed., Reconciliation: Nations and Churches in Latin America, (Aldershot: Ashgate, 2006), pp. 55-84.

40 Trexler, Sex and Conquest, 20; cited in Tombs 'Crucifixion, State Terror, and Sexual Abuse', 106-107.

41 On the gender norms and the notions of masculinity and penetration that would have supported displays of sexual violence against enemy male prisoners, see especially: Judith P. Hallett, and Marilyn Skinner, eds, Roman Sexualities, (Princeton, NJ: Princeton University Press, 1997); Craig A. Williams, Roman Homosexuality: Ideologies of Masculinity in Classical Antiquity, (New York and Oxford: Oxford University Press, 1999); Eva, Cantarella. Bisexuality in the Ancient World, Cormac Ó. Cuilleanáin, trans., (New Haven and London: Yale University Press, 1992). 


\subsection{When Did We See You Naked?}

The 1998 paper and the 1999 article were well-received, but the article's starting point in torture reports, and the use of liberation theology, may have been barriers to a greater impact in biblical scholarship. The central idea was initially taken up by a only a relatively small group of scholars. ${ }^{42}$ At a more popular level, however, Michael Irafrate's thoughtful discussion of 'Crucifixion, State Terror, and Sexual Abuse' in a blog-post in 2010 generated a very lively debate. ${ }^{43}$ Irafrate' reflection elicited a range of views both for and against the central contention and demonstrates the strong interest the argument attracts. ${ }^{44}$

When the \#MeToo movement erupted in October 2017 it seemed timely to revisit and develop the questions 'Crucifixion, State Terror, and Sexual Abuse' had raised. In 2016, the Centre for Theology and Public Issues at the University of Otago had undertaken a project on male victims of church based sexual abuse. ${ }^{45}$ A new project was already in preparation for 2018-2020 entitled 'When Did We See You Naked?' to connect the 2016 project with the earlier work on crucifixion. ${ }^{46}$ The first year of work, during 2018, was to address the stripping of Jesus. ${ }^{47}$ To help launch the project, Katie Edwards, Director of the

42 Biblical scholars who supported the central insight include: Gerald West, 'Indigenous Exegesis: Exploring the Interface between Missionary Methods and Rhetorical RhythmsLocating Local Reading Resources in the Academy', Neotestamentica,(2002) 36, 147-62; Jennifer A. Glancy, 'Torture: Flesh, Truth and the Fourth Gospel', Biblical Interpretation (2005) 13.2, 107-36; Sean A. Adams, 'Crucifixion in the Ancient World: A Response to L. L. Welborn' in Stanley E. Porter, ed. Paul's World, (Leiden and Boston: Brill, 2008).

43 Michael Iafrate, 'Was Jesus Raped?: David Tombs on Sexual Violence and the Crucifixion', Vox Nova: Catholic Perspectives on Culture, Society and Politics, (2 April 2010), <https:// www.patheos.com/blogs/voxnova/2010/04/o2/was-jesus-raped-david-tombs-on-sexual -violence-and-the-crucifixion/> [accessed 16 August 2019].

44 In March 2019, Mary Pezzulo referenced Iafrate's blog in her sequence of popular blogs on Jesus and sexual abuse, which started with Mary Pezzulo, 'Was Jesus Really Sexually Abused?', Patheos: Steel Magnificat, (7 March 2019) <https://www.patheos.com/blogs/ steelmagnificat/2019/03/was-jesus-really-sexually-abused/> [accessed 10 August 2019].

45 See Rocío Figueroa and David Tombs, "The Sodalicio Case in Peru: Lived Religion and the Traumatic Impact of Church Sexual Abuse' in Ruard Ganzevoort and Srdjan Sremac, eds, Lived Religion and Trauma: Transcending the Ordinary, (London: Palgrave McMillan, 2018), pp. 155-76; based on the report, Rocío Figueroa and David Tombs, Listening to Male Survivors of Church Sexual Abuse (Dunedin: Centre for Theology and Public Issues, University of Otago, 2016) <http://hdl.handle.net/10523/7052>.

46 See http://www.jaymereaves.com/naked. The project includes further collaboration with Rocío Figueroa on how acknowledgment of Jesus as a victim of sexual abuse is viewed by survivors of sexual abuse.

47 During 2017, a short Bible study on Mk 15:16-24 was developed for use with the project. The Bible study was first piloted with a working group of Anglican leaders at a Gender-Based Violence (GBV) Round Table at the Anglican Center in Rome, Italy (8-10 January 2018) organized by the Episcopal Relief and Development Agency. 
Sheffield Institute for Inter-Disciplinary Biblical Studies (sIIBs) arranged a special Shiloh Project lecture in January 2018. ${ }^{48}$ The lecture took the title ‘\#MeToo Jesus: Why Naming Jesus as a Victim of Sexual Abuse Matters'. ${ }^{49}$ The intention was threefold: to link the discussion of Jesus as a victim of sexual abuse to \#MeToo and the Gustavus Adolphus sign; to revisit the arguments which had been offered previously in 'Crucifixion, State Terror, and Sexual Abuse', and assess whether they stood the test of time; and to suggest why seeing Jesus in this way is not just an historical concern but matters far beyond this, and how it might connect to the \#MeToo movement.

The positive reception at sinss confirmed that the social relevance of this disturbing dimension to crucifixion had become much more obviously relevant than it had appeared twenty years previously. ${ }^{50}$ The next public event was a Lenten Lecture at St Paul's Anglican Cathedral Wellington (16 March 2018), which provided an opportunity to develop the argument on stripping and forced exposure in new ways. ${ }^{51}$ As part of the Lenten lecture, a short YouTube clip from the нво/ввс Series Rome (2005) was played. ${ }^{52}$ This video depicted the stripping of Vercingetorix, the chieftain of the Arverni, during his surrender to Caesar after the siege of Alesia in Gaul in $5^{2}$ BСЕ. The stripping is a fictionalized scene that is not attested in the historical sources. The clip is helpful, however, in depicting how the stripping and enforced display of a naked prisoner could be used to symbolize power and humiliation. It also appropriately conveys the menace of being stripped in front of a large gathering of soldiers

48 The Shiloh Project is a joint initiative set up by staff from the Universities of Sheffield, Leeds and Auckland to address rape culture, religion and the Bible; <www.shiloh-project .group.shef.ac.uk> [accessed 16 August 2019].

49 Jayme R. Reaves and David Tombs. “\#MeToo Jesus: Why Naming Jesus as a Victim of Sexual Abuse Matters', Special Shiloh Lecture at the University of Sheffield, 16 January 2018; video recording <http://shiloh-project.group.shef.ac.uk/special-lecture-professor-david-tombs -metoo-jesus $>$ [accessed 16 August 2019]. Nicola Slee at Queen's Ecumenical Theological Foundation, Birmingham, hosted a similar lecture the next day; Jayme R. Reaves and David Tombs, 'Acknowledging the Sexual Abuse of Crucifixion: \#MeToo as an Invitation to a New Conversation', 17 January 2019.

50 The interest in the lecture led to an interview on ввс Radio Sheffield's Sunday Breakfast Show; see 'Kat Cowan Interview with David Tombs and Jayme Reaves', ввс Radio Sheffield, (21 January 2018), <http://shiloh-project.group.shef.ac.uk/?p=2026> [accessed 16 August 2019].

51 The Lenten Lecture was part of a short series 'When Did We See You Naked?', (16-17 March). See David Tombs, 'Lord When Did I See You Naked', Anglican Taonga, (Winter 2018), 22-23, <https://issuu.com/anglican_taonga/docs/taonga_winter_2018_web_1/22>[accessed 16 August 2019].

$5^{2}$ The surrender of Vercingetorix is shown early in the first episode (titled 'The Stolen Eagle') in the first series of the television Rome (нво/ввС 2005). 
and hints at even worse violence which might follow for a prisoner. It did not need to actually happen to Vercingetorix to give an idea of why the stripping of Jesus should be seen as important rather than incidental. As the clip played, the Cathedral audience watched in thoughtful silence and, in the discussion afterwards, a number of participants mentioned its impact. The repeated stripping of Jesus in the praetorium was not something they had noticed before or given much thought to, but it now seemed more obviously significant. This was further discussed in a co-authored article by Edwards and Tombs in The Conversation the following week, which was picked up in the news media and received extensive media coverage. ${ }^{53}$ Woodhead observed that what might previously have sounded like an outlandish idea had suddenly started to seem more credible. ${ }^{54}$

\subsection{Recent Scholarship on Jesus as a Victim of Sexual Abuse}

Other scholars have also named Jesus as a victim of sexual abuse in recent years, including Elaine Heath, Wil Gafney, and Michael Trainor. ${ }^{55}$

Heath is a Professor of Mission and Pastoral Theology at Duke Divinity School in the United States. In a chapter on 'Emmanuel' in her book We Were the Least of These (2011), Heath addresses the strange silence of the churches on Jesus as a victim of sexual abuse. ${ }^{56}$ Heath is an ordained elder in the United Methodist church and describes her own experience of this silence in the church and in her theological training: 'I never heard a pastor preach about this in all my years in the church. Nor did I hear a professor talk about it when I went through graduate theological education. ${ }^{57}$

Heath notes the invisibility of this memory: 'None of us sees images or sculptures of Jesus naked in the church. Religious art always shows him with a loincloth. But Jesus was crucified naked. ${ }^{58}$ She contrasts artistic representations with what really happened and explains why the difference is important:

53 Katie B. Edwards and David Tombs, "\#HimToo — why Jesus should be recognised as a victim of sexual violence'. See also 'Should the stripping of Jesus be labelled sexual abuse?', Otago Daily Times, (16 Feb 2018) <https://www.odt.co.nz/opinion/should-stripping-jesus -be-labelled-sexual-abuse $>$ [accessed 17 Feb 2018].

54 Burgess, '\#HimToo'; see also Linda Woodhead, Unknowing God: Towards a Post-Abusive Theology (forthcoming).

55 See footnote 2 above. At the time of the Shiloh lecture (2018) we were aware of the work of Trainor and Gafney but we did not discover Heath's work until starting work on this article. Heath's book has recently been republished as Healing the Wounds of Sexual Abuse: Reading the Bible with Survivors, (Grand Rapids, MI: Brazos Press, 2019).

56 Heath, We Were the Least of These, pp. 121-34.

57 Ibid., p. 123 .

58 Ibid. 
'Being stripped publicly prior to his crucifixion was a calculated act of sexual violence. In Jesus's culture, as in Middle Eastern cultures today, to be stripped naked in front of a watching crowd was an act of sexual violation., ${ }^{59}$

Heath stresses the humiliation in the treatment of Jesus: 'The torture was sadistic, carried out while he was naked in order to maximize his humiliation in front of the voyeuristic crowd'. ${ }^{60}$ Heath is herself a survivor of sexual abuse and argues strongly that one of the reasons Jesus's sexual abuse has not been named is that the experiences of survivors have not been considered important in the formulation of Christology. ${ }^{61}$

Heath also notes that the connection between sexual abuse and crucifixion is much more overt in Christa images in which a female figure is represented as crucified. ${ }^{62}$ Christa figures have often attracted concern and criticism, however, and even complaints of blasphemy. ${ }^{63}$ She argues that the controversy which Christa figures often create is because they make an obvious connection between the sexual abuse of women and the crucifixion of Jesus, yet critics still miss the point in this representation. Heath writes: 'The inability of critics to make the obvious connection between Jesus, Christa, and the suffering of millions of women and girls boggles the mind. ${ }^{64}$

Heath also argues that although penal substitutionary models of the atonement have been presented as core to the 'good news' of the gospel, these models are often bad news for survivors of sexual violence. Penal substitution suggests that humanity deserves to be punished and to experience extreme suffering. ${ }^{65}$ Although, according to the penal substitutionary atonement model, Jesus stepped in as a substitute and took the punishment on himself, Heath argues that the underlying assumptions are still harmful. Heath, therefore, argues against models of atonement that present Jesus as suffering at the hands of a violent and vindictive God.

59 Ibid.

6o Ibid.

61 Ibid.

62 On the Christa image, see especially: Julie Clague, 'Interview with Margaret Argyle', Feminist Theology, 10 (September 1995), 57-68; Julie Clague, 'The Christa: Symbolizing My Humanity and My Pain', Feminist Theology, 14:1 (2005), 83-108; Julie Clague, 'Divine Transgressions: The Female Christ-form in Art', Critical Quarterly, 47:3 (2005), 47-63; Nicola Slee, Seeking the Risen Christa, (London: SPCK Publishing, 2011); Nicola Slee, 'Visualizing, Conceptualizing, Imagining and Praying the Christa: In Search of Her Risen Forms', Feminist Theology, 21:1, 71-90.

63 Heath, We Were the Least of These, p. 124.

64 Ibid., p. 124.

65 Ibid., pp. 125-32. 
A number of feminist theologians have criticized the punitive values behind penal substitution, as well as other models of atonement. The well-known collection by Brown and Bohn scrutinizes many of the troubling assumptions behind various traditional models of atonement with different contributors arguing these models promote a sense of sacrificial suffering in an uncritical way which contributes to violence against women. ${ }^{66}$ The chapter by Brown and Parker pushes this connection further to link some models of atonement with patriarchal child abuse, highlighting how some versions of atonement present God as an abusive father who sacrifices his son, Jesus, on the cross. ${ }^{67}$ Despite these feminist critiques of atonement models and their discussion of violence against women and child abuse, however, the connection to the historical sexual abuse of Jesus is not explicitly addressed. None of the chapters directly names the cross as an historical act of sexual abuse or sexual violence. It might be possible to read some of the contributors as coming very close to making this connection, and it may perhaps have been in the mind of some writers to some extent, but it is not explicitly stated in their contributions. Likewise, later work by Rebecca Parker and Rita Nakashima Brock comes very close at a number of points to identifying Jesus as a victim of abuse, but does not explicitly name sexual abuse as part of Jesus' actual experience. ${ }^{68}$

Another U. S. scholar who does make the connection explicit is Wil Gafney. Gafney is an African-American bible scholar and an Anglican (Episcopalian) Priest. ${ }^{69}$ Her teaching includes a course on The Bible and Black Lives Matter, which 'examines the core claims and commitments of the Black Lives Matter movement in light of the biblical text with an eye to preaching and teaching the scriptures in response to the extra-judicial killings of black women and men'.70 Gafney's work is informed by black and womanist theologies and draws on the long history of racial violence in the United States for her analysis of crucifixion. Gafney writes:

66 Joanne Carlson Brown and Carole R. Bohn, eds.), Christianity, Patriarchy and Abuse: A Feminist Critique (Cleveland, OH: Pilgrim Press, 1989).

67 Joanne Carlson Brown and Rebecca Parker, 'For God So Loved the World?' in Brown and Bohn, eds., Christianity, Patriarchy and Abuse, pp. 1-30.

68 Rita Nakashima Brock and Rebecca Ann Parker, Saving Paradise: How Christianity Traded Love of This World for Crucifixion and Empire, (Boston: Beacon Press, 2008).

69 Gafney publishes under the titles Wil Gafney and Wilda Gafney, and has pioneered work in womanist biblical interpretation and midrash; see Wilda C. Gafney, Womanist Midrash: A Reintroduction to the Women of the Torah and the Throne, (Louisville, KY: Westminster: John Knox Press, 2017).

Wil Gafney, <http://www.wilgafney.com/media-kit/> [accessed 18 Sept 2018]. 
On this Good Friday [2013] as on many before, I consider anew the full range of torture and humiliation to which Jesus of Nazareth was subjected, physical and sexual. The latter is so traumatizing for the Church that we have covered it up-literally-covering Jesus' genitals on our crucifixes. But the Romans (and others) who used crucifixion as more than a form of execution, as a form of state-sponsored terrorism - really lynching - to control subject populations were not inclined to respect the human or religious dignity, culture or customs of their targets. ${ }^{71}$

The connection Gafney makes between crucifixion and lynching echoes James Cone's work on The Cross and the Lynching Tree, which shows the value of reading lynching in light of crucifixion and vice-versa. ${ }^{72}$ Although Cone's book does not address sexual violence as a significant link between the lynching and crucifixion, Gafney's writing suggests how this might be developed as a further strand of the connection between lynching and crucifixion. ${ }^{73}$ Sexual violence often accompanied a lynching, but this is often excluded from public memory and public discussion. Even when the castrations or genital mutilations of lynching are remembered, they are more likely to be framed as an abhorrent and outlandish detail rather than as something of central importance and a subject for theological focus. Gafney notes that sexual violence in crucifixion and lynching is not incidental but serves a purpose: 'The combination of various forms of sexualized violence and lethal violence are potent dehumanizing expressions of dominance as in ritual castrations combined with lynching in the American South—and North' ${ }^{74}$

Racialized sexual violence of this kind is confronting and requires sensitivity and careful analysis to ensure that the victims are treated with respect and remembered with dignity. Gafney's work shows how this can be done appropriately to make the sexual violence of crucifixion and lynching mutually illuminating. To omit such violence from consideration, or imply that it is not really important, would be to do a different type of violence to the dignity of the victims.

71 Wil Gafney, 'Crucifixion and Sexual Violence', Huffington Post (28 March 2018); also available as Wil Gafney blog, 'Crucifixion and Sexual Violence', <http://www.wilgafney .com/2013/o3/> [accessed 12 Sept 2018].

72 James H. Cone, The Cross and the Lynching Tree, (Maryknoll, NY: Orbis Books, 2011).

73 See also David Tombs, 'The Cross, the Lynching Tree and the Silences', in Black Theology Group 'Gender and Sexual Violence in Black Theological Anthropology' at American Academy of Religion Annual Meeting, Chicago, 18 November 2012.

Gafney, 'Crucifixion and Sexual Violence'. 
A third scholar to have written on Jesus and sexual abuse is the Australian biblical scholar and Catholic Priest Michael Trainor. His work is especially helpful because he offers a sustained and detailed book-length treatment of the New Testament texts on crucifixion. ${ }^{75}$ Trainor's reading is shaped by his awareness of violence against women and also the pastoral crisis of clergy sexual abuses in Australia and many other countries. ${ }^{76}$

Trainor shares insights offered by his students from discussions during his teaching on the passion narratives. Some of these students share how their experiences of abuse have influenced their reading of these passages. ${ }^{77} \mathrm{~A}$ further strength of Trainor's work is that he treats the four gospels separately and identifies the similarities and differences in each. He observes that 'each of the gospel stories of Jesus' passion ... can legitimately be heard as stories of abuse' but they each pick up on a different aspect. ${ }^{78}$ Trainor recognizes that the abuse was both physical and sexual and the intention was to 'victimise, dehumanise and eradicate any sense of Jesus' social identity'. ${ }^{79}$ He notes that this abuse was integral to crucifixion and that 'the convicted one's public humiliation is well documented' 80 There is no question that this should be named as sexual abuse:

Ancient texts outside the Second Testament can also help us get a sense of what crucifixion would mean in the Greco-Roman, Jewish world, particularly as a heinous form of public punishment, designed to expose its victim to the utmost public ridicule, shame and abuse. In a powerful and public way, it was an act of sexual abuse. ${ }^{81}$

Given the very public debate which has taken place over church sexual abuses in Australia in recent years, it is extraordinary that Trainor's work has not

75 Michael Trainor, Body of Jesus and Sexual Abuse; see also Michael Trainor, 'Sexual Abuse and Luke's Story of Jesus' in Hilary D. Regan, ed, Child Sexual Abuse, Society, and the Future of the Church, (Adelaide: ATF Australia, 2013); Michael Trainor, 'Matthew's Passion Narrative: The Abuse of Jesus (Part One)', Compass: A Review of Topical Theology 36.2 (2002), pp. 43-47; Michael Trainor, 'Matthew's Passion Narrative: The Physical and Sexual Abuse of Jesus (Part Two)', Compass: A Review of Topical Theology 36.3 (2002), pp. 24-31; Michael Trainor, 'Mark's Passion Narrative: A story of Abuse and Failed Intimacy', Compass: A Review of Topical Theology 37.1 (2003), pp. 39-44.

76 Ibid., p. 245 .

77 Ibid., pp. 9-10, 245 .

78 Ibid., p. 247 .

79 Ibid., p. 254 .

8 o Ibid.

81 Ibid., p. 42. 
received more attention. The silence with which the book has been received suggests a deep discomfort in discussion of the topic. Newspapers, radio, and television have carried regular stories of church related abuses and a book by a Catholic Priest identifying Jesus as a victim of sexual abuse might expect to be highly newsworthy. Despite this, when Trainor spoke at a 'When Did We See You Naked?' event in Auckland in 2018, he said the invitation to New Zealand was the first time he had ever been asked anywhere to give a public lecture on his book. ${ }^{82}$

Although Tombs, Heath, Gafney and Trainor all worked independently from each other, they share at least three insights in common. First, that Jesus was a victim of sexual abuse and that he should be acknowledged as such. Second, that punitive humiliation was central to the abuse, and that sexual violence is a highly effective way to do this. Humiliation serves to degrade and dehumanize the victim in the eyes of others, and undermines their own sense of self and self-worth. Understanding the sexual abuse in terms of punitive humiliation, rather than sexual gratification, is crucial for understanding the logic and rationale of the abuse. Third, the failure to see this more clearly before now is in large part due to the artistic representations which misrepresent the historical scene and suppress the disturbing truth. As Heath notes, Christian art rarely presents Jesus as fully naked. Even when the stripping of Jesus at the cross is represented, as it often is in depictions of the Tenth Station of the Cross, artistic depictions tend to suppress the sense of violence and threat in the scene. ${ }^{83}$ Since Christian imagination is firmly shaped by this artistic tradition, it then becomes difficult to see what is in the texts, or to recognise that the visual tradition is so clearly at odds with the texts. The statement that Jesus was a victim of sexual abuse initially appears so strange because the visual art makes it so hard to see the texts in this way. As Trainor says:

82 Michael Trainor, 'The Body of Jesus and Sexual Abuse', Public Lecture at Holy Cross Seminary, Auckland (27 April 2018); Trainor's lecture was followed the next day by a symposium 'The Abused Christ: Theologians Respond to Sexual Abuse', at Good Shepherd College, Auckland.

83 Christian art rarely shows the full picture, and more usually distorts it or covers it up. Depictions of the stripping at the cross often show just a handful of people surrounding Jesus and only two or three involved in the stripping. It is possible that John 20:23a is a factor in this, since it suggests only four soldiers were directly involved: 'When the soldiers had crucified Jesus, they took his clothes and divided them into four parts, one for each soldier'. This is very different to 'the whole cohort' in the earlier stripping in Mk 15:16 and Mt 27:27. Even so, it appears that John 20:23a is applied to the scene selectively. In many depictions the figures are not shown in uniforms and are not recognisably Roman. This fits with Christian attempts to excuse the Romans from blame. 
Our presumption that the body of the crucified Jesus was clothed is fed by our sexual propriety reinforced by the typical iconographic representation of his crucifixion. This depiction shows a strategically placed loin cloth across the victim's genital area, a decorous gesture not known to be practiced by first century CE Roman executioners. ${ }^{84}$

Furthermore, Tombs, Heath, Gafney, and Trainor, can each be seen as standing within wider respective streams of scholarship (liberationist, feminist, womanist and pastoral) where others have written on Jesus in relation to abuse, but have stopped short of explicitly naming Jesus as an historical victim of sexual abuse.

Some of the recent responses to naming Jesus as a victim of sexual abuse mistakenly assume that the \#MeToo movement is the original basis for understanding him this way. This perception makes it easy to dismiss the idea as a simplistic 'co-opting' of Jesus for \#MeToo, and describe it as 'farcical' and 'ahistorical. ${ }^{85}$ In one newspaper column, British pundit Janet Street-Porter describes the idea as 'offensive and trivialising' and cites it as a reason to 'wonder if the \#MeToo bandwagon is running out of control': 86

These objections are in keeping with an established pattern. When people first hear the bald statement that Jesus was a victim of sexual abuse without further explanation or evidence they find it implausible and even absurd.$^{87}$ Yet people who have heard the evidence or read more about the argument are much more likely to give positive responses. ${ }^{88}$ Often people say they had not

84 Trainor, Body of Jesus and Sexual Abuse, p. 26.

85 Stuart Waiton cited in Victoria Allen, “\#HimToo": Jesus Christ was a victim of sexual abuse when he was stripped to be crucified, says university academic', Daily Mail, (27 March 2018) <https://www.dailymail.co.uk/news/article-5546839/HimToo-Jesus -Christ-victim-sexual-abuse.html> [accessed 27 March 2018].

86 Janet Street-Porter, 'Including Jesus in the \#MeToo movement is a step too far', Independent, (30 March 2018) <https://www.independent.co.uk/voices/metoo-movement-sexual -assault-jesus-holy-week-john-worboys-a8281156.html> [accessed 30 March 2018]. Street-Porter adds that 'This weekend is a sacred time for Christians ...' with the implication that the suggestion is inappropriate because of its intrusion on the sancity of Easter.

87 These reactions are clear in the predominantly negative comments left in the media coverage and in responses to the paper Katie B. Edwards and David Tombs, ‘\#HimToo—why Jesus should be recognised as a victim of sexual violence'.

88 See, for example, Woodhead, 'Is Jesus the latest—or was he the first—victim of \#MeToo?'. 
thought about it before, and never heard it called sexual abuse before, but now they have thought about it and they see that it is correct. Some people are even quite puzzled and self-critical that they did not see it this way before, noting how obvious it now appears.

Clarifying the historical record to reveal the truth in this way is important, and contributes to the work of biblical studies and historical research. But for public theology, this clarification is more of a starting point than an end point. Why does it matter now? What purpose does it serve to open up this painful and disturbing history? What role does it have in a public theology?

Part of the answer that can be given to these broader questions is that acknowledgment of Jesus as victim of sexual abuse has extraordinary potential to open up a new conversation within churches. This assumption is not to suggest that the churches should only think sexual abuse is important if Jesus was a victim. Sexual abuse should be a concern for the churches regardless of who is experiencing it. ${ }^{89}$ Nonetheless, for many in churches, the experience of Jesus offers a pressing reason to think more deeply about sexual abuse. In addition to providing this pressing reason, Jesus' experience is also significant because of the way that churches think about Jesus, especially in relation to innocence and blame.

The reality that victims of sexual violence are often directly or indirectly blamed for sexual violence is widely recognized. Questions about what they wore, where they were, how they may have provoked or invited what happened can all serve to shift the blame from perpetrators to victims of sexual violence. ${ }^{90}$ In addition, even if the victims of sexual violence are not directly blamed, they may still be viewed differently because of what has happened. The abuse still has power to shame and tarnish survivors in the eyes of others even when they are not seen as in some way responsible. They are often seen as somehow tainted or reduced in standing compared to before. This reduced state is durable and it is not easy recover from it. What has happened is often seen as 'degrading', or 'defiling' or 'despoiling' them in the eyes of others and perhaps even in their own eyes. Talk of a 'loss of innocence' or 'loss of purity' can suggest the impact is irreversible. Studies in shame, stigma, and

89 Conversely, it is not to suggest that Jesus 'needed' to be a victim of sexual abuse for his slow and painful death to be horrific. Nor is to suggest that he 'needed' to experience sexual abuse so that he would know and share in all forms of suffering. The point is that, historically speaking, he was a victim of sexual abuse, not that he needed to be.

go This dynamic often becomes even clearer when contrasted with other crimes. For example, victims of burglary are much less likely to face scrutiny on how they might have contributed to what happened. 
perceptions of purity are helpful for what is going on here and show how survivors can be judged negatively even if they are not explicitly blamed. ${ }^{91}$

The stigmatising of survivors can be more pernicious because other people may be unaware that that they are doing this. Most people, especially church people, have a self-image of altruism and care for others. Respectable church people will invariably insist that they follow Christian teaching: they seek to care for their neighbours and extend compassion to those in need. This makes it easy to claim that they would not, and do not, victimise survivors. Nonetheless, survivors often say that they experience negative and judgemental attitudes. Church responses frequently stem from unexamined attitudes to shame and stigma which rest beneath the surface within the churches. Most of the time these negative attitudes are not recognised and so continue unexamined. They only surface when prompted by an encounter with a survivor of sexual violence, and are often expressed indirectly through a silence or unspoken judgement. In some cases, a survivor might be the target of gossip or rumour. In other cases, the negative attitude comes through the silence. If a church never speaks of sexual violence, nor acknowledges those who have suffered from it, it can seem that the church does not want to know about it, and that the experiences of survivors are unimportant. When the experiences of survivors are never addressed in church, it is easy for survivors to take this as a message that there is something wrong with them. Either what they did (victim blaming), or what they have become (victim stigmatising), or both, makes them unworthy in the eyes of respectable church members.

The initial reaction which many people in churches experience when they hear the statement 'Jesus was a victim of sexual abuse' often reflects these complex undercurrents. ${ }^{92}$ The statement is heard as making Jesus somehow less worthy. Nobody is likely to suggest that Jesus must have been to blame for it, but it can initially seem difficult to imagine how he might continue to be treated with the same respect or revence.

The stigma and expected loss of respect may be why the statement that Jesus was a victim of sexual abuse is often fiercely resisted. The operating assumption appears to be that, if it were true, it would lower Jesus in the eyes of decent people. Respectable church members wish to defend Jesus from such a fate, and to protect the Christian faith from such a concession. This reaction does not need to be a conscious response; it can happen at a more instinctive

91 See especially, Erving Goffman's classic work, Stigma: Notes on the Management of Spoiled Identity, (New York and London: Simon \& Schuster, 1963).

92 'Jesus sexually abused when stripped, crucified, theologian says', Morning Report, Radio New Zealand (18 April 2019); https://www.radionz.co.nz/audio/player?audio_id=2018691531. 
level. An instinctive dismissal is easy enough as a quick reaction to the simple declaration that Jesus was a victim of sexual abuse without further elaboration. But it becomes much harder when the text is read carefully. For those who take the text seriously, the evidence usually becomes compelling. Recent work developing contextual Bible studies on Mk 15:15-24 and Mt 27:26-31 supports this claim. When the first century historical evidence is examined and what is known of sexual abuses in contemporary contexts are considered, the argument usually becomes convincing. This acts as a bridge to a deeper conversation on the difference this makes to how Christians might see Jesus and how churches might respond differently to survivors of sexual abuse. Interviews with a group of male survivors of church related sexual abuse in Peru indicated that all eight of the men interviewed believed that the sexual abuse of Jesus was an important issue for the whole church and not just for survivors of abuse. ${ }^{93}$

Commenting on the Independent Inquiry into Child Sexual Abuse (IICSA) first series of hearings on Child Sexual Abuse in the Anglican Church in England and Wales (5-23 March 2018), Woodhead has argued that although a change in culture within the church is necessary, cultural change will fall short if it does not also extend to theology. ${ }^{94}$ Woodhead argues that a theology of forgiveness that supported abuse needs to be reconsidered. Likewise, naming Jesus as a victim of sexual abuse would provide impetus for a more urgent discussion of how other areas of church theology, including a naïve Christology, must be scrutinised and rethought in light of abuse scandals.

A potentially positive aspect of these discussions is that the special status of Jesus in Christianity strongly resists the blaming and shaming discussed above. Jesus is the one person who is usually viewed within the churches as faultless and blameless. Likewise, Christians are very unlikely to suggest that Jesus is less worthy as a religious leader because of what was done to him.

93 Rocío Figueroa Alvear and David Tombs, Recognising Jesus as a Victim of Sexual Abuse: Responses from Sodalicio Survivors in Peru. (Dunedin: Centre for Theology and Public Issues, University of Otago, 2019); http://hdl.handle.net/10523/8976 (English); http://hdl.handle.net/10523/9222 (Spanish); http://hdl.handle.net/10523/9386 (Polish); David Tombs. 'How Recognising Jesus as a victim of sexual abuse might help shift Catholic culture', The Conversation, (13 March 2019) <http://theconversation.com/how -recognising-jesus-as-a-victim-of-sexual-abuse-might-help-shift-catholic-culture-112754> [accessed 13 March 2019].

94 Woodhead writes: 'Nobody who spoke at IICSA, including Archbishop Welby, denies that the problem goes deep and calls for serious reform. Everyone agreed that procedural and structural change was insufficient without a change of culture. But no one drew the obvious conclusion that this must include theology'; Linda Woodhead, 'Forget culture. It's a new theology we need', in Church Times, (6 April 2018). 
Therefore, the suggestion that Jesus experienced sexual abuse is highly disruptive and disconcerting to the notionally respectable Christian view, which so readily stigmatizes victims. Recognising Jesus as a victim challenges the prejudice that a victim of sexual abuse is somehow at fault and/or spoilt by their experience. ${ }^{95}$ Naming Jesus as a victim of sexual abuse therefore matters far more than is obvious at first. It is not just getting the historical record correct, it can make a real difference to how survivors see themselves and how they are perceived and treated by others. ${ }^{96}$ Further research is required around survivor responses but many individual survivors have spoken of their appreciation of this reading and the practical difference it has made to them. In the words of one survivor: 'When I was abused, I never imagined that God could understand my shame. 97

\section{5 Conclusion}

An understanding of crucifixion as a form of sexual abuse has started to be more widely recognised in recent publications. Whether crucifixion is viewed from the perspectives of torture (Tombs), lynching (Gafney), or sexual abuse (Heath and Trainor), the sexual element in crucifixion is coming into clearer focus. Yet there is still a long way to go for this to become fully appreciated in the church, the academy, or wider society.

95 See David Tombs, 'Confronting the Stigma of Naming Jesus as a Victim of Sexual Violence' in Clive Pearson ed, Enacting a Public Theology, (Stellenbosch: SunMedia, forthcoming 2019), pp. 71-86.

96 These practical implications require more sustained research and investigation, especially with survivors. On the dangers of valorizing the silence and steadfast suffering of Jesus, see especially: Rita Nakashima Brock and Rebecca Parker, Proverbs of Ashes: Violence, Redemptive Suffering and the Search for What Saves Us. (Boston: Beacon Press, 2001); Katie B. Edwards and Meredith Warren, '\#MeToo Jesus: is Christ really a good model for victims of abuse?', The Conversation, (14 February 2018) <https://theconversation .com/metoo-jesus-is-christ-really-a-good-model-for-victims-of-abuse-91812> [accessed 14 February 2018].

97 Personal conversation with author following David Tombs, "When Did We See You Naked?" Re-reading the Stripping of Jesus in the Context of \#MeToo', in Bible and Practical Theology Session: Biblical Texts with the \#MeToo Movement, Society of Biblical Studies Annual Meeting, Denver, 19 November 2018. The Figueroa and Tombs interviews with male survivors in Peru suggested a more complex picture. They all saw it as important for the church, with four survivors identifying it as helpful for survivors, and four seeing it as irrelevant; Figueroa and Tombs, Recognising Jesus as a Victim of Sexual Abuse. Some of the responses on its personal value may reflect that these interviewees no longer identify as religious. 
Exploring what is easily ignored or unseen, and uncovering what may be concealed or hidden within the crucifixion story, can make a profound contribution to church and society attitudes toward victims of sexual violence today. Sexual abuse and sexual violence are daily realities for those who experience oppression and discrimination in any society. Jesus' experience of sexual abuse carries extraordinary potential for significant change within the churches on how sexual violence might be seen and how the needs of survivors should be addressed. The naming of Jesus as a victim challenges churches to rethink misplaced attitudes that contribute to blaming, stigmatization, and shaming. It helps the churches to see that these negative responses are present, even when they are initially denied, and it can help to show why this must change. The issues highlighted by \#MeToo, \#ChurchToo, \#SilenceIsNotSpiritual, and church sexual abuse scandals, thereby offer a belated opportunity for transformative renewal within theology, and within the church. 